Note

\title{
Soil respiration in cucumber field under crop rotation in solar greenhouse
}

Yinli Liang ${ }^{1,2 *}$, Caihong Bai ${ }^{1}$, Lan $\mathrm{Mu}^{2}$, Maojuan Zhou ${ }^{3}$

${ }^{1}$ Northwest A\&F University/Institute of soil and Water Conservation, Yangling Shaanxi - 712100 - China.

${ }^{2}$ The Chinese Academy of Sciences and Ministry of water Resource/Institute of soil and Water Conservation, Yangling Shaanxi - 712100 - China.

${ }^{3}$ Shandong Polytechnic University/College of Light Chemical and Environmental Engineering/Key Lab. of Cleaner Production and Industrial Waste Recycling and Resourcization in Universities of Shandong, Changqing, Jinan, Shandong 250353 - China.

*Corresponding author <liangy|@ms.iswc.ac.cn>

Edited by: Carlos Eduardo Pellegrino Cerri

Received July 12, 2013

Accepted March 26, 2014
ABSTRACT: Crop residues are the primary source of carbon input in the soil carbon pool. Crop rotation can impact the plant biomass returned to the soil, and influence soil respiration. To study the effect of previous crops on soil respiration in cucumber (Cucumis statirus L.) fields in solar greenhouses, soil respiration, plant height, leaf area and yield were measured during the growing season (from the end of Sept to the beginning of Jun the following year) from 2007 to 2010. The cucumber was grown following fallow (CK), kidney bean (KB), cowpea (CP), maize for green manure (MGM), black bean for green manure (BGM), tomato (TM), bok choy (BC). As compared with $\mathrm{CK}, \mathrm{KB}, \mathrm{CP}, \mathrm{MGM}$ and $\mathrm{BGM}$ may increase soil respiration, while TM and $\mathrm{BC}$ may decrease soil respiration at full fruit stage in cucumber fields. Thus attention to the previous crop arrangement is a possible way of mitigating soil respiration in vegetable fields. Plant height, leaf area and yield had similar variation trends under seven previous crop treatments. The ratio of yield to soil respiration revealed that MGM is the crop of choice previous to cucumber when compared with $\mathrm{CK}, \mathrm{KB}, \mathrm{CP}, \mathrm{BGM}, \mathrm{TM}$ and $\mathrm{BC}$.

Keywords: Leaf area, $\mathrm{CO}_{2}$ emission, plant height, previous crop, yield

\section{Introduction}

Soil microbial respiration is the major carbon dioxide $\left(\mathrm{CO}_{2}\right)$ emission from soil released into the atmosphere and has vital importance in the global carbon budget (Schimel, 1995; Raich and Tufekcioglu, 2000). The respiratory activities of plant roots and their mycorrhizal fungi in soil as a proportion of the total soil respiration were estimated from 10 to 90 \% (Hanson et al., 2000; Högberg et al., 2001; Raich and Tufekcioglu, 2000). Soil respiration is affected by several factors, such as soil temperature and moisture, root biomass, net primary productivity, litter inputs, microbial populations, fertility, soil organism, soil texture, substrate quantity and quality (Boone et al., 1998; Fang et al., 1998; Buchmann, 2000; Sánchez et al., 2003; Dilustro et al., 2005; Han et al., 2007; Iqbal et al., 2010).

Crop residues (above and below ground) are the primary source of carbon input in the soil carbon pool but crop rotation can also impact the plant biomass returned to the soil, thereby influencing soil quality, total microbial biomass, microbial activity, basal respiration, specific maintenance respiration, total organic carbon, active carbon, total nitrogen, aggregate stability, particulate organic matter, $\mathrm{C}: \mathrm{N}$ ratio and soil organic matter decomposition (Adiku et al., 2008; Ferreira et al., 2010; Aziz et al., 2011). Therefore, crop rotation has the potential to affect soil respiration (Halvorson et al., 2002; Lal, 2004, 2005; Russell et al., 2005). However, the influence of crop residues on soil respiration depends upon amount, type and size of the crop residues added.

Greenhouse cucumber production is very popular in many areas of the world (Soleimani et al., 2009). Cucumber fields account for $10 \%$ of vegetable land (about
$20 \mathrm{Mha})$, and about $50 \%$ of cucumber planted in greenhouses in China $(\mathrm{Li}, 2010)$. In Shaanxi province, cucumber accounts for around $60 \%$ of the vegetables in greenhouses (0.9 Mha) (Chen et al., 2004). However, there is a lack of information about the effects of previous crops on soil respiration in cucumber fields in solar greenhouses in Shaanxi province.

In order to compare soil respiration in cucumber fields under the six previous treatments of crops that are commonly used in this area by farmers, and evaluate the usefulness of previous crops in reducing soil $\mathrm{CO}_{2}$ emission in China, soil respiration, plant height, leaf area and yield were measured in cucumber fields during the growing season. Our objectives were: (i) to understand soil respiration in cucumber fields under the six previous crop treatments; (ii) to investigate cucumber growth under the six previous crop treatments; and (iii) to find an optimal rotation system that will reduce soil respiration without decreasing cucumber yield.

\section{Materials and Methods}

\section{Experiment site}

This study was carried out in a cucumber field in a solar greenhouse covered with transparent polyethylene film in Yan'an $\left(36^{\circ} 48^{\prime} \mathrm{N} ; 1^{\circ} 9^{\circ} 18^{\prime} \mathrm{E}\right)$, Shannxi Province of China. The mean annual air temperature in the region is about $9.3^{\circ} \mathrm{C}$, and the annual precipitation is around $540 \mathrm{~mm}$ at the site of the experiment site. The site itself, where the experiment was conducted, is relatively flat, and the soil is a silty-loamy Inceptisol. The initial values of soil organic matter, $\mathrm{pH}$ and bulk density were $10.3 \mathrm{~g}$ $\mathrm{kg}^{-1}, 8.3$ and $1.15 \mathrm{~g} \mathrm{~cm}^{-3}$ respectively. 


\section{Experiment design and management}

The researchers used a randomized block design with three replicates, and the size of each plot was 17.28 $\mathrm{m}^{2}(7.2 \mathrm{~m} \times 2.4 \mathrm{~m})$. Cowpea (Vigna unguiculata) $(\mathrm{CP})$, kidney bean (Phaseolus vulgaris) (KB), black bean (Phaseolus vulgaris) (BGM), maize (Zea mays L.) (MGM), bok choy (Brassica rapa chinensis) (BC) were seeded, and tomato (Solanum lycopersicum L.) (TM) was transplanted $60 \mathrm{~cm}$ apart in rows and $30 \mathrm{~cm}$ apart inter-plants on the $13^{\text {th }}$ of June. They were harvested on the $15^{\text {th }}$ Sept 2007, 2008 and 2009, while maize and black bean were chopped into 5-10 $\mathrm{cm}$ chip and introduced into the soil on the $10^{\text {th }}$ of August as green manure. The aboveground parts of cowpea, kidney bean, bok choy and tomato were removed after harvest, and the underground parts left in the soil.

Cucumber seedlings with five leaves were transplanted on $29^{\text {th }}$ Sept 2007, 2008 and 2009. All cucumber fruit harvesting was ended on the $5^{\text {th }}$ June 2008, 2009 and 2010. Soil water content was about 60-80\%. We measured the soil water content once a week, if the water content was lower than $60 \%$, we irrigated with about $30 \mathrm{~mm}$ of water using a drip irrigating system. $\mathrm{N}$ at $75 \mathrm{~kg}$ $\mathrm{ha}^{-1}, \mathrm{P}_{2} \mathrm{O}_{5}$ at $125 \mathrm{~kg} \mathrm{ha}^{-1}$ and $\mathrm{K}_{2} \mathrm{O}$ at $75 \mathrm{~kg} \mathrm{ha}^{-1}$ were applied as a base fertilizer when the soil was turned over. Furthermore, the same amount of fertilizer $(\mathrm{N}$ at $75 \mathrm{~kg}$ $\mathrm{ha}^{-1}, \mathrm{P}_{2} \mathrm{O}_{5}$ at $75 \mathrm{~kg} \mathrm{ha}^{-1}$ and $\mathrm{K}_{2} \mathrm{O}$ at $75 \mathrm{~kg} \mathrm{ha}^{-1}$ ) was applied on the $28^{\text {th }}$ Nov and the $26^{\text {th }}$ Feb for the three years of the experiment, respectively. In each greenhouse, air temperature and relative humidity were followed by a Temperature/Relative Humidity Data Logger every hour, every day during the cucumber growing season. The average values of ten days are presented in Figure 1.

\section{Soil respiration measurements}

A closed polymethyl methacrylate chamber was used to measure the soil respiration on the $15^{\text {th }} \mathrm{Feb}$,

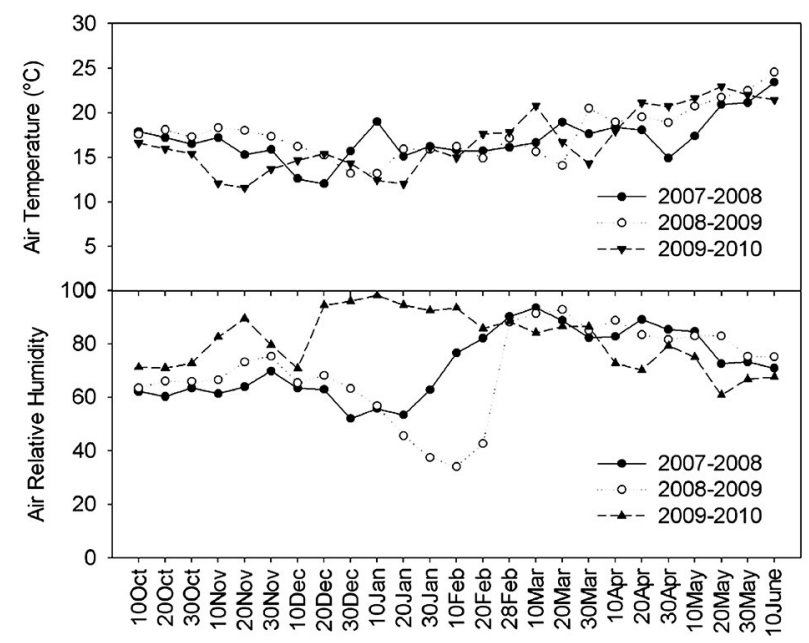

Figure 1 - Air temperature and relative humidity during the growing season of cucumber in the greenhouse. the $15^{\text {th }}$ Apr and the $18^{\text {th }}$ May 2008, the $15^{\text {th }}$ Feb, the $15^{\text {th }}$ Apr and the $16^{\text {th }}$ May 2009, the $15^{\text {th }}$ Feb, the $15^{\text {th }}$ Apr and the $15^{\text {th }}$ May 2010 at the full fruit stage. Three measurements were taken from each treatment on each observation day so that soil respiration from 2008, 2009 and 2010 would each have 3 days of measurements. The area of the bottom of the chamber was $400 \mathrm{~cm}^{2}$ (length and width were $20 \mathrm{~cm}$ ), and the height was 30 $\mathrm{cm}$. The closed chamber on each experimental plot was placed inter-plants (about $15 \mathrm{~cm}$ from the center of the chamber to the plants) and inter-rows (i.e. in the middle of four plants, about $23 \mathrm{~cm}$ from the center of chamber to the plant). The edge of the chamber was inserted into the soil $2-3 \mathrm{~cm}$ after litters were removed. The chamber covered the alkali bottle $(\mathrm{NaOH})$. In bottles, excess $\mathrm{BaCl}_{2}$ was used. The alkali bottles were left in the field for $3 \mathrm{~h}$ from $8 \mathrm{~h} 00$ to $11 \mathrm{~h} 00$. The alkali was corked by rubber stoppers and taken to the laboratory. Total $\mathrm{CO}_{2}$ was determined by titration with $0.1 \mathrm{M} \mathrm{HCl}$ (Ivo and Salcedo 2012).

The chemical equations were:

$$
\begin{aligned}
& 2 \mathrm{NaOH}+\mathrm{CO}_{2}=\mathrm{Na}_{2} \mathrm{CO}_{3}+\mathrm{H}_{2} \mathrm{O} \\
& \mathrm{Na}_{2} \mathrm{CO}_{3}+\mathrm{BaCl}_{2}=2 \mathrm{NaCl}+\mathrm{BaCO}_{3} \downarrow \\
& \mathrm{NaOH}+\mathrm{HCl}=\mathrm{NaCl}+\mathrm{H}_{2} \mathrm{O}
\end{aligned}
$$

The calculation of the soil respiration was done by the following equation:

$\mathrm{CO}_{2}\left(\mathrm{gCO}_{2} \mathrm{~m}^{-2} \mathrm{day}^{-1}\right)=\left[\left(\mathrm{V}_{1}-\mathrm{V}_{2}\right) \times \mathrm{N} \times \mathrm{M}\right] /(2 \times 1000 \times \mathrm{A} \times \mathrm{T})$

in which $\mathrm{V}_{1}$ : total volume of $\mathrm{NaOH}$ solution; $\mathrm{V}_{2}$ : volume of $\mathrm{HCl}$ solution reacted with $\mathrm{NaOH} ; \mathrm{N}$ : $\mathrm{HCl}$ concentration; $\mathrm{M}$ : molar mass of $\mathrm{CO}_{2}$; $\mathrm{A}$ : determination area; $\mathrm{T}$ : determination time.

Plant height and leaf area measurements: these were measured from the ground to the top of the main plants stems with a ruler. The area of completely expended leaves was measured in a leaf area meter, taking the total leaf area of all leaves of one plant as leaf area. The average of ten plants was recorded as plant height and leaf area for each plot.

Yield measurements: the fresh weight of each plot was recorded as the amount of fruit weight during the growing season. The criterion for harvesting was the standard fresh-market cucumber (length is around $32-38 \mathrm{~cm}$, fruit color is dark green).

Data analysis: one-Way ANOVA with previous crops as the factor was performed with SPSS 16.0 for Windows (USA) for yield, plant height and leaf area. The mean difference is significant at the 0.05 level. 


\section{Results and Discussion}

Soil respiration in cucumber fields under the six previous crop treatments at the full fruit stage was different $(p<0.05)$ (Figure 2A). Similar trends in soil respiration, were found in 2008, 2009 and 2010, and soil respiration under $\mathrm{KB}, \mathrm{CP}, \mathrm{BGM}$ and $\mathrm{MGM}$ was higher than CK. Soil respiration under TM and BC was lower $(p<0.05)$ than CK. Soil respiration in cucumber fields under MGM, CP, KB and BGM treatments were higher $(p<0.05)$ than control $(\mathrm{CK})$, and the average soil respiration of the three experimental years under MGM, CP, KB and BGM treatments were 1.01, 0.91, 0.73, $0.57 \mathrm{gCO}_{2}$ $\mathrm{m}^{-2}$ day $^{-1}$ higher than $\mathrm{CK}$, respectively.
Soil respiration under TM and $\mathrm{BC}$ treatments were lower $(p<0.05)$ than $\mathrm{CK}$, the average soil respiration of the three experimental years under TM and $\mathrm{BC}$ treatments being 0.72 and $0.74 \mathrm{gCO}_{2} \mathrm{~m}^{-2}$ day ${ }^{-1}$ lower than $\mathrm{CK}$, respectively. A possible reason is, in the case of $\mathrm{CP}, \mathrm{KB}$ and BDM treatments, that the previous crops were legume which promoted soil respiration in cucumber fields. Franchini et al. (2007) also reported $\mathrm{CO}_{2}$ was $13 \%$ higher with lupin (Lupinus L.) residues than with wheat (Triticum Aestivum L.) straw. Legumes (cowpea, kidney bean and black bean) can form symbiotic associations for nitrogen fixation with Rhizobium, the Rhizobium fixes nitrogen into a form that the plant can use. Nitrogen from the legume might increase the rate of decomposition of soil
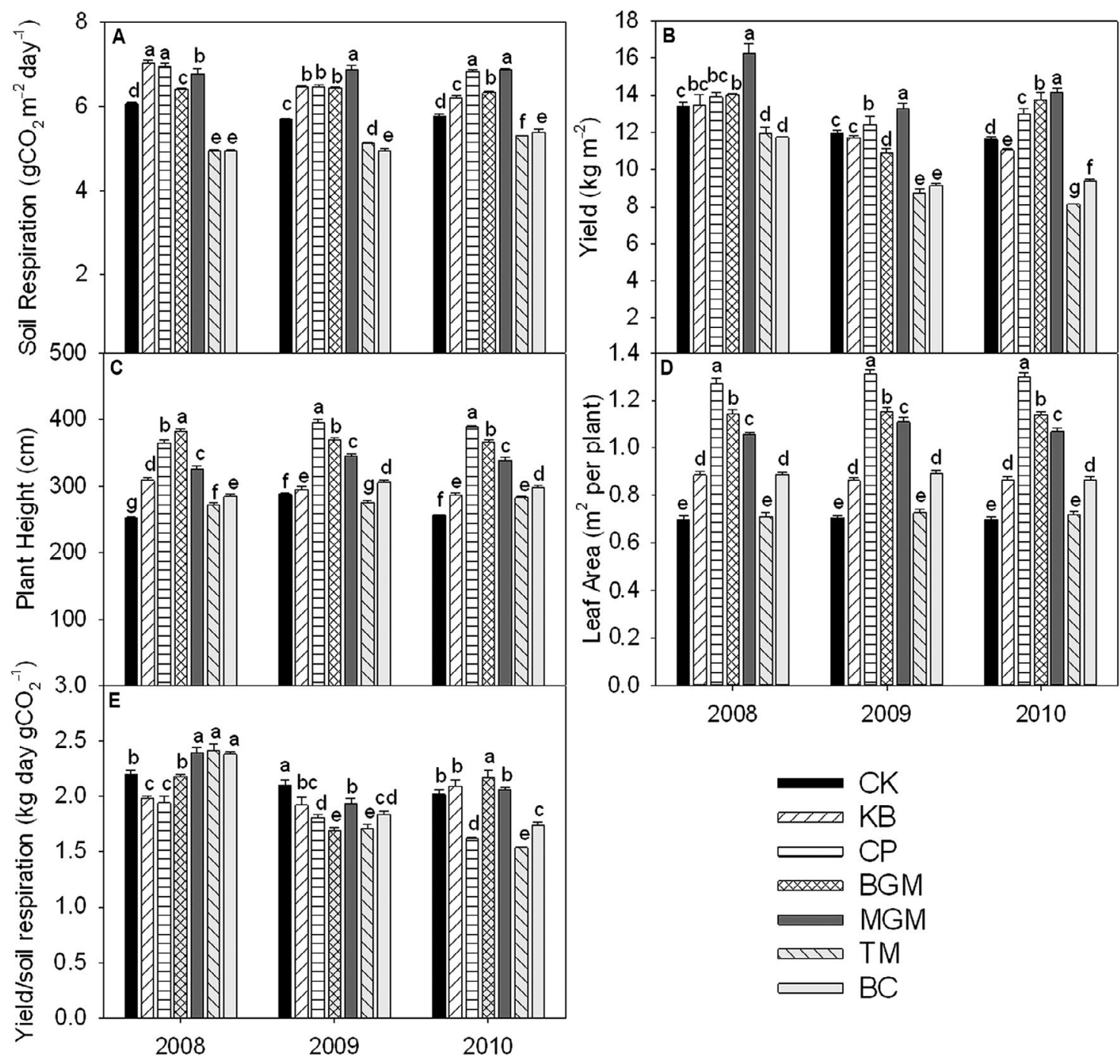

Figure 2 - Soil respiration at the full fruit stage, yield, plant height, leaf area and ratio of yield to soil respiration in cucumber field under fallow and six previous crops treatments in 2008, 2009 and 2010. Different letters mean differences between treatments in the same year ( $p<0.05$ ) based on the LSD test. CK - Fallow; BC - bok choy; MGM - maize for green manure; CP - cowpea; TM - tomato; KB - kidney bean; BGM - black bean for green manure. 
organic carbon. Lu et al. (2011) found that soil respiration (containing autotrophic and heterotrophic respiration) increased by $4.3 \%$ in response to $\mathrm{N}$ fertilization.

Since the root respiration coefficient was positively correlated with root $\mathrm{N}$ content, the root nitrogen content may account for $91 \%$ of the change in the root respiration coefficient during the maize growing season. However, in this study, soil respiration under MGM treatment was among the highest obtained, though maize is non-legume. Because fresh maize green manure (about two months old) is the main soil organic matter source for decomposition, the amount of maize biomass which was turned over into the soil was much larger than for other crops, and the organic content in MGM was the highest (unpublished data), which stimulated soil respiration. In addition, the soil organic matter composition of crop residues in $\mathrm{CP}, \mathrm{KB}, \mathrm{BGM}$ and MGM treatments in this study may influence $\mathrm{CO}_{2}$ and soil microbial quantity/ activity (van Hees et al., 2005), and $\mathrm{CO}_{2}$ release from organic decay and microbial respiration will be subsequently affected. Furthermore, crop residue in $\mathrm{CP}, \mathrm{KB}, \mathrm{BGM}$ and MGM treatments could affect the acquisition of soil nutrients (e.g. N, P, K and so on) and soil pH. Consequently, root respiration and other root activities such as ion uptake and root growth were influenced (Veen, 1981; Hafner et al., 1993). Therefore, the root respiration CP, KB, BGM and MGM treatments were higher than in TM and CP treatments and $\mathrm{CK}$.

Figures 2C and 2D present the plant height and leaf area of cucumber under CP, BGM, MGM, KB, TM and $\mathrm{BC}$ treatments which were higher than $\mathrm{CK}$, in the years studied. The yield of cucumber under MGM treatment was higher $(p<0.05)$ than CK (Figure 2B) and increased by $21 \%, 11 \%$ and $22 \%$ in 2008, 2009 and 2010, respectively, as compared with CK. The yield of cucumber under TM and BC treatments was lower than CK in 2008, 2009 and 2010 (Figure 2B). Under TM treatment, the yield decreased by $11 \%, 27 \%$ and $30 \%$ in 2008, 2009 and 2010, respectively, as compared with $\mathrm{CK}$; under BC treatment, the yield decreased by $12 \%, 23 \%$ and $19 \%$ in 2008, 2009 and 2010, respectively, as compared with CK.

There were no regression relationships between soil respiration and plant height and leaf area, but there was a regression relationship between cucumber yield and soil respiration (Table 1). The relationship between cucumber yield and soil respiration was closer than that between plant height or leaf area of cucumber and soil respiration.
The correlation analysis also showed that fruit yield was positively correlated ( $p<0.05$ ) with soil respiration (Table 1). These results further suggested that the previous crop residue affected both the above ground and root growth of plants, and cucumber yield and soil respiration varied in the six previous crop treatments.

For cucumber production, high yield is the aim of farmers. However, low $\mathrm{CO}_{2}$ emission is one of the components of carbon budget. The ideal crop rotation should result in high productivity and low $\mathrm{CO}_{2}$ emission. We calculated the ratio of yield to soil respiration to assess the effect of previous crops on soil respiration and yield in cucumber fields (Figure 2E). The cucumber fields under MGM, CP, KB and BGM treatments emitted more CO2 while higher cucumber yields were also produced, and the cucumber fields under BC and TM treatments emitted less $\mathrm{CO}_{2}$ and lower cucumber yields were also produced. The ratios of yield to soil respiration under each treatment varied in 2008, 2009 and 2010. However, the ratio under MGM was relatively higher and more stable than under other previous crop treatments in 2008, 2009 and 2010, respectively.

He et al. (2009) reported that the soil urease activity was higher under MGM treatment than under other treatments. Urease activity in soil may originate from plant residues, animal waste or soil microbes containing urease (Dharmakeerthi and Thenabadu, 1996). The amount of residue in the soil presumably altered urease activity. Urease plays an important role in carbon metabolism, as it can rapidly hydrolyse urea $\left(\mathrm{NH}_{2} \mathrm{CONH}_{2}+\mathrm{H}_{2} \mathrm{O}\right.$ $\rightarrow 2 \mathrm{NH}_{3}+\mathrm{CO}_{2}$ ) in soil, which results in $\mathrm{CO}_{2}$ emission. Thus, the addition of crop residues containing urease increases the rate of urea hydrolysis (Barreto and Westerman, 1989). Urease is an important indication of soil fertility (He et al., 2009), and soil urease activity under MGM treatment is the highest among previous crop treatments with the result that soil fertility under MGM treatment is the highest, which improved the yield of cucumber. Therefore, MGM could be the most suitable of crops to precede cucumber.

\section{Conclusions}

Soil respiration in cucumber field under MGM, CP, $\mathrm{KB}$ and $\mathrm{BGM}$ treatments was higher than $\mathrm{CK}$ and soil respiration under TM and BC treatments were lower than CK. Similar tendencies were found for yield, plant height

Table 1 - Regression between soil respiration and yield, plant height and leaf number.

\begin{tabular}{|c|c|c|c|c|c|c|}
\hline \multirow{3}{*}{ Traits } & \multicolumn{6}{|c|}{ Soil respiration $\left(\mathrm{gCO}_{2} \mathrm{~m}^{-2}\right.$ day $^{-1}$ ) } \\
\hline & \multicolumn{2}{|l|}{2008} & \multicolumn{2}{|l|}{2009} & \multicolumn{2}{|l|}{2010} \\
\hline & Regression Function & $\mathrm{R}^{2}$ & Regression Function & $\mathrm{R}^{2}$ & Regression Function & $\mathrm{R}^{2}$ \\
\hline Yield $\left(\mathrm{kg} \mathrm{m}^{-2}\right)$ & $Y=1.28 x+5.65$ & $0.59^{*}$ & $Y=1.95 x+0.556$ & $0.77^{* *}$ & $Y=3.16 x-7.66$ & $0.81^{* *}$ \\
\hline Plant Height (cm) & $P H=31.7 x+117$ & 0.35 & $P H=39.1 x+90.2$ & 0.41 & $P H=56.3 x-26.4$ & 0.55 \\
\hline Leaf Area & $L A=0.145 x+0.0542$ & 0.37 & $L A=0.150 x+0.0406$ & 0.34 & $L A=0.290 x-0.815$ & $0.68^{*}$ \\
\hline
\end{tabular}

${ }^{*}$ Significant $(p<0.01) .{ }^{*}$ Significant $(p<0.05) . Y=$ yield; $P H=$ plant height; $L A=$ means leaf area; $x=$ soil respiration. 
and leaf area. To reduce soil respiration and have relatively high yield, MGM was the most suitable previous crop as compared to other previous crops.

\section{Acknowledgements}

This work was supported by National Science and Technology Support Program, No. 2014B AD14B006 and "Strategic Priority Research Program-Climatic Change: Carbon Budget and Relevant Issues" of the Chinese Academy of Sciences, Grant No. XDA05050504.

\section{References}

Adiku, S.G.K.; Narh, S.; Jones, J.W.; Laryea, K.B.; Dowuona, G.N. 2008. Short-term effects of crop rotation, residue management, and soil water on carbon mineralization in a tropical cropping system. DOI 10.1007/s11104 0089652 y.

Aziz, I.; Ashraf, M.; Mahmood, T.; Islam, K.R. 2011. Crop rotation impact on soil quality. Pakistan Journal of Botany 43: 949-960.

Barreto, H.J.; Westerman, R.L. 1989. Soil urease activity in winter wheat residue management systems. Soil Science Society of America Journal 53: 1455-1458.

Boone, R.D.; Nadelhoffer, K.J.; Canary J.D.; Kaye J.P. 1998. Roots exert a strong influence on the temperature sensitivityof soil respiration. Nature 396: 570-572.

Buchmann, N. 2000. Biotic and abiotic factors controlling soil respiration rates in Picea abies stands. Soil Biology and Biochemistry 32: 1625-1635.

Chen, Z.; Zhang, S.; Liang, Y.; Zhang, F.; Xu, F.; Quan, Q. 2004. Effect of bagging on greenhouse cucumber. Chinese Journal Appllied Ecology 15: 1297-1300 (in Chinese, with abstract in English)

Dharmakeerthi, R.S.; Thenabadu, M.W. 1996. Urease activity in soils: a review. Journal of the National Science Council of Sri Lanka 24: 159-195.

Dilustro, J.J.; Collins, B.; Duncan, L.; Crawford, C. 2005. Moisture and soil texture effects on soil $\mathrm{CO}_{2}$ efflux components in southeastern mixed pine forests. Forest Ecology and Management 204: 85-95.

Fang, J.; Liu, S.; Zhao, K. 1998. Factors affecting soil respiration in reference with temperature's role in the global scale. Chinese Geographical Science 8: 246-255.

Ferreira, E.P.D.B.; Santos, H.P.D.; Costa, J.R.; De-Polli, H.; Rumjanek, N.G. 2010. Microbial soil quality indicators under different crop rotations and tillage management. Revista Ciência Agronômica 41: 177-183.

Franchini, J.C.; Crispino, C.C.; Souza, R.A.; Torres, E.; Hungria, M. 2007. Microbiological parameters as indicators of soil quality under various soil management and crop rotation systems in southern. Brazil Soil Tillage Research 92: 18-29.

Halvorson, A.D.; Wienhold, B.J.; Black, A.L. 2002. Tillage, nitrogen, and cropping system effects on soil carbon sequestration. Soil Science Society of America Journal 66: 906-912.

Hafner, H.; George, E.; Bationo, A.; Marschner, H. 1993. Effect of crop residues on root growth and phosphorus acquisition of pearl millet in an acid sandy soil in Niger. Plant and Soil 150: 117-127.
Han, G.; Zhou, G.; Xu, Z.; Yang, Y.; Liu, J.; Shi, K. 2007. Soil temperature and biotic factors drive the seasonal variation of soil respiration in a maize (Zea mays L.) agricultural ecosystem. Plant and Soil 291: 15-26.

Hanson, P.J.; Edwards, N.T.; Garten, C.T.; Andrew, J.A. 2000. Separating root and soil microbial contributions to soil respiration: a review of methods and observations. Biogeochemistry 48: 115146.

He, L.; Liang, Y.; Xiong, Y.; Zhou, M.; Gao, J.; Wei, Z. 2009. Effect of different proceding crops on yield, quality of cucumber and soil enzyme activity in solar greenhouse. Chinese Journal of EcoAgriculture 17: 24-28.

Hees, P.A.W. van; Jones, D.L.; Findlay, R.; Godbold, D.L.; Lundstrom, U.S. 2005. The carbon we do not seed - the impact of low molecular weight compounds on carbon dynamics and respiration in forest soils: a review. Soil Biology and Biochemistry 37: 1-13.

Högberg, P.; Nordgren, A.; Buchmann, N.; Taylor, A.F.S.; Ekblad, A.; Högberg, M.N.; Nyberg, G.; Lofvenius, M.O.; Read, D.J. 2001. Large-scale forest girdling shows that current photosynthesis drives soil respiration. Nature 411: 789-792.

Iqbal, J.; Hu, R.G.; Feng, M.L.; Lin, S.; Malghani, S.; Ali, I.M. 2010. Microbial biomass, and dissolved organic carbon and nitrogen strongly affect soil respiration in different land uses: a case study at Three Gorges Reservoir Area, South China. Agriculture Ecosystem and Environment 137: 294-307.

Ivo, W.M.P.M.; Salcedo, I.H. 2012. Soil $\mathrm{CO}_{2}$ efllux: A method comparison of closed static chambers in a sugarcane field. Revista Brasileira de Ciencia do Solo 36: 421-426.

Lal, R. 2005. World crop residues production and implications of its use as a biofuel. Environment International 31: 575-584.

Lal, R. 2004. Agricultural activities and the global carbon cycle. Nutrient Cycling in Agroecosystems 70: 103-116.

Li, Z. 2010. The key cultivation techniques of Cucumber (Cucumis sativus L.). Modern Agriculture 1: 11 (in Chinese).

Lu, M.; Zhou, X.; Luo, Y.; Yang, Y.; Fang, C.; Chen, J.; Li, B. 2011. Minor stimulation of soil carbon storage by nitrogen addition: a meta-analysis. Agriculture Ecosystem and Environment 140: 234-244.

Raich, J.; Tufekcioglu, A. 2000. Vegetation and soil respiration: correlations and controls. Biogeochemistry 48: 71-90.

Russell, A.E.; Laird, D.A.; Parkin, T.B.; Mallarino, A.P. 2005. Impact of nitrogen fertilization and cropping system on carbon sequestration in Midwestern mollisols. Soil Science Society of America Journal 69: 413-422.

Sánchez, M.L.; Ozores, M.I.; López, M.J.; Colle, R.; Torre, B.De.; García, M.A.; Pérez, I. 2003. Soil $\mathrm{CO}_{2}$ fluxes beneath barley on the central Spanish plateau. Agricultural and Forest Meteorology 118: 85-95.

Schimel, D.S. 1995. Terrestrial ecosystems and the carbon cycle. Global Change Biology 1: 77-91.

Soleimani, A.; Ahmadikhah, A.; Soleimani, S. 2009. Performance of different greenhouse cucumber cultivars (Cucumis sativus L.) in southern Iran. African Journal of Biotechnology 8: 4077-4083.

Veen, B.W. 1981. Relation between root respiration and root activity. Plant and Soil 63: 73-76. 